\title{
Management of root rot and damping off complex in French bean by biocontrol agents
}

\author{
SUNIL C. DUBEY ${ }^{\star *}$, ARADHIKA TRIPATHI ${ }^{2}$, RAKESH TAK and S. INDIRA DEVI ${ }^{3}$ \\ ${ }^{1}$ Division of Plant Quarantine, ICAR-National Bureau of Plant Genetic Resources, New Delhi 110 012, India \\ ${ }^{2}$ Division of Plant Pathology, ICAR-Indian Agricultural Research Institute, New Delhi 110 012, India \\ ${ }^{3}$ Department of Microbiology, Institute of Bio-resources and Sustainable Development, Imphal 395001 , Manipur, India
}

Received: 10 April 2017/ Accepted: 24 June 2017/ Published online: 24 July 2017

(C) Indian Phytopathological Society 2017

\begin{abstract}
French bean (Phaseolus vulgaris) is one of the important food legume crops used as green vegetable and pulse in different parts of India. Among the diseases, root rot (Rhizoctonia solani) and damping off (Pythium ultimum) complex are considered an important factor for low productivity of the crop. The experiments were conducted during 2013 and 2014 at IARI, New Delhi to evaluate the performance of different seed dressing and soil application formulations of Trichoderma species and talc based formulation of Pseudomonas fluorescens (IBSD-P137) against root rot and damping off complex in French bean. The seeds treated with seed dressing formulations of Trichoderma and Pseudomonas alone and in combinations increased the seed germination, root and shoot lengths, plant dry weight and pod yield and decreased the disease incidence. The seeds treated with Pusa 5SD ( $T$. harzianum-IARI P4) in combination with $P$. fluorescens gave the highest seed germination, shoot and root length, dry plant weight and pod yield along with the lowest disease incidence followed by Pusa 5SD (T. harzianum-IARI P4) alone and Pusa 5SD (T. viride; IBSD T-20) in combination with IBSD isolate of $P$. fluorescens. Seed germination, root length and disease incidence in these treatments did not differ significantly. Soil application of Pusa bio-pellets of T. harzianum (IARI P4) and T. viride (IBSD T-20) also enhanced the seed germination, shoot and root lengths, dry plant weight and pod yield and reduced disease incidence. Thus, the root rot and damping off in French bean could be managed by soil application and seed treatment with bio-formulations of $T$. harzianum alone and in combination with $P$. fluorescens.
\end{abstract}

Keywords: French bean, bio-formulation, disease management, root rot, damping off, Trichoderma, Pseudomonas

French bean (Phaseolus vulgaris L.) is one of the most important vegetable food legumes directly consumed worldwide. Root rot and damping off of French bean caused by Rhizoctonia solani Kühn and Pythium ultimum Trow, respectively are the most devastating diseases occurring together as a complex (El-Mougy et al., 2007). The pathogens survive in the soil as sclerotia in case of $R$. solani and as fungal mycelia/oospores in case of Pythium ultimum separately or embedded with host tissues and may destroy the entire crop under favorable conditions.

Use of bio-control agents in place of fungicides is an alternative to manage the plant diseases, which can reduce the environmental pollution and enhance the safety of agricultural produces. Various methods to manage such diseases namely, chemical, cultural practices, plant volatile compounds, plant extracts including the use of resistant varieties and biological methods, particularly the use of species of Trichoderma have been investigated (El-Mougy et al., 2007). The potential of Trichoderma species has been demonstrated by several workers in controlling the damping-off and root rot diseases of crop plants caused by Rhizoctonia

${ }^{*}$ Corresponding author: scdube2002@yahoo.co.in and Pythium species (Dubey, 2002; Dubey et al., 2007).

The application of Trichoderma species provided protection against pre- and post-emergence damping off and reduced the disease incidence as compared to fungicide (Abd-El-Khair et al., 2011). The seed treatment with $T$. harzianum based bioformulation significantly increased the heights and weight of plants and significantly reduced the incidence of damping-off in various leguminous crops (Abd-El-Khair et al., 2011; Negi et al., 2014). Trichoderma asperellum, T. harzianum, and T. viride, checked the black mould rot severity in onion (Prajapati and Patil, 2017).

The objective of the present study was to evaluate the efficacy of $T$. harzianum and $T$. viride based bioformulations alone and along with $P$. fluorescens against root rot and damping off complex caused by $R$. solani and $P$. ultimum in French bean.

Pot experiments were conducted during 2013 and 2014 at Division of Plant Pathology, IARI, New Delhi in completely randomized block design to evaluate the performance of different seed dressing and soil application formulations of Trichoderma species and 
Pseudomonas fluorescens (IBSD-P137) against root rot (R. solani) and damping off ( $P$. ultimum) of French bean. Surface sterilized plastic pots ( $15 \mathrm{~cm}$ diameter) were filled with sterilized (formalin $1.0 \%$ ) soil $\left(2 \mathrm{~kg} \mathrm{pot}^{-1}\right)$. The inoculum of both the pathogens was multiplied on sorghum grains (Sorghum bicolor) and the pot soil were inoculated with the 10 days old mixed inoculum of $R$. solani (5 g kg-1 of soil) and P. ultimum (5 g kg-1 of soil) two days before sowing (Dubey et al., 2009). The seeds were treated with bioformulations separately and in combination with fungicides. Twelve treatments evaluated against the disease were consisted of Pusa 5SD ( $T$. viride, IBSD T20) from IBSD, Imphal, Pusa 5SD ( $T$. harzianum IARI-P4) from IARI, New Delhi, talc based formulation of Pseudomonas fluorescens (IBSD-P137), Pusa 5SD ( T. viride IBSD T20) + talc formulation of $P$. fluorescens (IBSD-P137), Pusa 5SD (T. harzianum IARIP4) + talc formulation of $P$. fluorescens (IBSD-P137), carbandezim + thiram, Pusa biopellets prepared from $T$. viride (IBSD T20) and T. harzianum (IARI-P4) including controls. Each pot was sown with 6 seeds of susceptible French bean variety Contender on February 18, 2013 and February 21, 2014. Each treatment was replicated three times. The seed treatment was performed with bioformulations at $6 \mathrm{~g} \mathrm{~kg}^{-1}$ seed and soil application formulations were applied at $0.5 \mathrm{~g} \mathrm{~kg}^{-1}$ soil in required pots prior sowing. The fungicides were applied in 1:1 ratio at $2 \mathrm{~g} \mathrm{~kg}^{-1}$ seed.

Germination of seeds was recorded at 10 days after sowing. Shoot and root lengths, and dry weight were recorded on the basis of two plants uprooted at maturity stage from each pot. Pod weights were recorded at harvesting time from each pot. Number of diseased plants from each pot were counted periodically and finally, disease incidence was calculated based on total diseased plants per pot. The data pertaining to all the observations were subjected to ANOVA (Gomez and Gomez, 1984) using the SAS Software (SAS Institute, version 9.1, Cary, NC). The data were analyzed as per the procedure for a completely randomized design for the test of significance. Mean of two years data were presented. Fisher's Protected Least Significant Differences (LSD) was computed only when ANOVA showed significant differences for any particular effect.

The seeds treated with seed dressing formulations of Trichoderma species and $P$. fluorescens alone and in combination increased the seed germination, root and shoot lengths, plant dry weight and pod yield and decreased the disease incidence (Table 1). The highest seed germination, shoot and root lengths, dry plant weight and pod yield along with the lowest disease incidence were recorded in the seeds treated with Pusa 5SD (T. harzianum-IARI P4) in combination with IBSD, Imphal isolate of $P$. fluorescens $(\mathrm{P}-137)$ followed by Pusa 5 SD ( T. harzianum-IARI P4) alone, Pusa 5SD (T. viride, IBSD T-20) in combination with $P$. fluorescens (IBSD P137) and Pusa 5SD (T. viride, IBSD T-20) alone were the next effective treatment in order of performance. Seed germinations, root length and disease incidence recorded in these treatments did not differ significantly. Soil application of Pusa biopellets of T. harzianum (IARI P4) and $T$. viride (IBSD T-20) also enhanced the seed germination, shoot and root lengths, dry plant weight and pod yield and reduced disease incidence. Seed germination, shoot and root lengths and dry plant weight, pod yield and disease incidence recorded in these treatments were significantly superior over the control having mixed inoculum of both the pathogens.

The seed germination and disease incidence recorded in the seeds treated with $T$. harzianum $+P$. fluorescens were statistically similar with non-inoculated

Table 1. Effect of seed treatment and soil application on yield attributing factors and disease incidence in French bean (mean of two year 2013 and 2014)

\begin{tabular}{|c|c|c|c|c|c|c|}
\hline Treatment details & $\begin{array}{c}\text { Germination } \\
(\%)\end{array}$ & $\begin{array}{l}\text { Shoot length } \\
(\mathrm{cm})\end{array}$ & $\begin{array}{l}\text { Root length } \\
(\mathrm{cm})\end{array}$ & $\begin{array}{l}\text { Dry weight } \\
\text { (mg/plant) }\end{array}$ & $\begin{array}{l}\text { Pod weight } \\
\text { (g/pot) }\end{array}$ & $\begin{array}{c}\text { Disease } \\
\text { incidence } \\
(\%)\end{array}$ \\
\hline Pusa 5SD (Trichoderma viride, IBSD T-20) & $95.8(84.0)^{\mathrm{abc}}$ & $24.1^{b}$ & $9.3^{\mathrm{ab}}$ & $1194.4^{c}$ & $19.3^{b}$ & $6.6(10.5)^{\mathrm{ab}}$ \\
\hline Pusa 5SD (T. harzianum, IARI P-4) & $95.8(84.0)^{\mathrm{abc}}$ & $24.4^{b}$ & $9.8^{\mathrm{ab}}$ & $1298.6^{b}$ & $25.9^{a}$ & $4.5(9.0)^{\mathrm{ab}}$ \\
\hline Pseudomonas fluorescens (IBSD P-137) & $87.5(71.9)^{\text {cde }}$ & $23.3^{\mathrm{bc}}$ & $7.6^{c}$ & $1058.2^{\mathrm{de}}$ & $17.6^{\mathrm{cd}}$ & $13.1(19.4)^{\mathrm{bc}}$ \\
\hline $\begin{array}{l}\text { Pusa 5SD (T. viride, IBSD T-20) + } \\
\text { P. fluorescens (IBSD P-137) }\end{array}$ & $95.8(84.0)^{\mathrm{abc}}$ & $24.3^{b}$ & $9.7^{\mathrm{ab}}$ & $1295.8^{b}$ & $19.5^{b}$ & $5.0(9.4)^{\mathrm{ab}}$ \\
\hline $\begin{array}{l}\text { Pusa 5SD (T. harzianum, IARI- P4) + } \\
\text { P. fluorescence (IBSD P-137) }\end{array}$ & $97.9(87.0)^{\mathrm{ab}}$ & $27.1^{\mathrm{a}}$ & $10.0^{\mathrm{a}}$ & $1538.9^{a}$ & $26.7^{\mathrm{a}}$ & $4.5(9.0)^{\mathrm{ab}}$ \\
\hline Carbendazim + Thiram & $83.3(65.9)^{d e}$ & $22.9^{c}$ & $7.0^{\mathrm{cd}}$ & $1054.5^{\mathrm{de}}$ & $16.6^{d}$ & $13.1(19.4)^{\mathrm{bc}}$ \\
\hline Pusa Biopellet ( T. viride, IBSD T-20) & $89.6(74.9)^{\mathrm{bcd}}$ & $23.5^{\mathrm{bc}}$ & $8.8^{\mathrm{b}}$ & $1074.0^{\text {de }}$ & $17.6^{\mathrm{cd}}$ & $9.0(14.4)^{\mathrm{abc}}$ \\
\hline Pusa Biopellet (T. harzianum, IARI P-4) & $89.6(74.9)^{\mathrm{bcd}}$ & $23.6^{\mathrm{bc}}$ & $9.4^{\mathrm{ab}}$ & $1130.8^{\mathrm{cd}}$ & $18.8^{\mathrm{bc}}$ & $9.0(14.4)^{\mathrm{abc}}$ \\
\hline Control (Rhizoctonia solani) & $75.0(60.3)^{\mathrm{e}}$ & $22.3^{\text {cd }}$ & $5.9^{\text {de }}$ & $1002.1^{\text {ef }}$ & $13.3^{\text {ef }}$ & $20.7(27.0)^{\mathrm{cd}}$ \\
\hline Control (Pythium ultimum) & $79.2(63.1)^{\mathrm{de}}$ & $22.9^{c}$ & $5.9^{\mathrm{de}}$ & $1027.7^{\text {ef }}$ & $14.6^{\mathrm{e}}$ & $20.7(27.0)^{c d}$ \\
\hline Control (R. solani + P. ultimum) & $72.9(58.9)^{\mathrm{e}}$ & $21.2^{\mathrm{d}}$ & $5.4^{\mathrm{e}}$ & $945.5^{f}$ & $12.8^{f}$ & $21.9(27.9)^{d}$ \\
\hline Control (No inoculum) & $100.0(90.0)^{a}$ & $24.7^{b}$ & $6.9^{\mathrm{cd}}$ & $1077.0^{\text {de }}$ & $18.4^{\mathrm{bc}}$ & $2.3(4.6)^{\mathrm{a}}$ \\
\hline
\end{tabular}

Figures in parentheses are transformed angular values

The values within a column with different letters are significantly different at $5 \%$ level by using Fisher's least significance difference test 
control. Whereas, pod yield and other yield attributing parameters like shoot and root lengths, dry plant and pod weight were higher than the non-inoculated control showed the growth enhancing ability of the bioagents used for treatments. The present results are supported by the observations of Nashwa et al. (2008) that $T$. harzianum and $T$. viride showed greatest antagonistic efficacy on Fusarium oxysporum f. sp. phaseoli and $R$. solani causing damping-off and wilt in bean plants. Soil treatment with Trichoderma formulation reduced significantly the disease incidence and enhanced the green yield of bean plants under green house and field conditions. Abd-El-Khair et al. (2011) observed that soil treatment with Trichoderma species significantly reduced the pre and post emergence damping- off incidence in beans caused by F. solaniand $R$. solani. In present results also, the soil application of Trichoderma based formulations Pusa Biopellets, significantly reduced the disease in French beans and increase yield attributing parameters, but their performance was less than seed treatment. Hamid et al. (2012) managed the root rot in pea caused by $F$. solani f. sp. pisi using T. harzianum, carbendazim and P. fluorescens.

Negi et al. (2014) also observed increase in shoot, root and seedling lengths, number of pods, grains per pod, pod weight and yield of vegetable pea raised with the seeds treated with a combination of $T$. harzianum and $P$. fluorescens. The seed treatment reduced the root rot complex caused by $R$. solani and $F$. solani in vegetable pea. In the present findings also, combined application of $T$. harzianum and $P$. fluorescens significantly enhanced the yield attributing parameters and yield of French bean and minimized the disease incidence. The treatment also enhanced the shoot and root lengths of the French bean plants indicating the growth promoting properties of the formulations. Plant growth enhancement properties of Trichoderma has been observed in beans (HoyosCarvajal et al., 2009). The seed priming of cowpea with T. harzianum improved the seed germination, vigour of plants, pod number and pod vigour and reduced root and collar rot caused by R. solani (Pan and Das, 2011). Soil application of $T$. harzianum along with vermi-compost reduced the disease (Pan and Das, 2011). Abd-El-Khair et al. (2011) also observed that soil treatment with Trichoderma species significantly reduced the pre- and post-emergence damping-off incidence in beans caused by $F$. solani and $R$. solani. In present results also, the soil application of Trichoderma species formulations Pusa Biopellets, significantly reduced the disease in French bean and increase yield attributing parameters, but their performance was less than seed treatment.

Trichoderma viride along with salicylic acid increased growth parameters and yield, and reduced the damping off and root rot/wilt in Faba bean (AbdelMonaim, 2013). El-Mohamedy et al. (2015) managed the root rot of green bean caused by $R$. solani and F. solani using seed treatment with $T$. harzianum and resistance inducer chemicals sorbic or benzoic acid. In the present study, a combination of $T$. harzianum and $P$. fluorescens proved effective in managing the root rot and damping off complex in French bean and increased yield attributing parameters and yield.

\section{ACKNOWLEDGEMENTS}

Authors are thankful to the Department of Biotechnology (DBT), New Delhi, India for financial support.

\section{REFERENCES}

Abd-El-Khair H, Khalifa R Kh M, Karima and Haggag HE (2011). Effect of Trichoderma species on damping off diseases incidence, some plant enzymes activity and nutritional status of bean plants. J. Am. Sci. 7: $156-167$.

Abdel-Monaim MF (2013). Improvement of Biocontrol of Damping-off and Root Rot/Wilt of Faba Bean by Salicylic Acid and Hydrogen Peroxide. Mycobiology 41: 47-55.

Dubey SC (2002). Bioagent based integrated management of collar rot of French bean. Indian Phytopath. 55: 230-231.

Dubey SC, Bhavani R and Singh Birendra (2009). Development of Pusa 5SD for seed dressing and Pusa Biopellet 10G for soil application formulations of Trichoderma harzianum and their evaluation for integrated management of dry root rot of mungbean (Vigna radiata). Biol. Control 50: 231-242.

Dubey SC, Suresh M and Singh B (2007). Evaluation of Trichoderma species against Fusarium oxysporum f.sp. ciceris for integrated management of chickpea wilts. Biol. Control 40: 118-127.

El-Mohamedy, Riad RS, Shafeek MR and Rizk FA (2015). Management of root rot diseases and improvement growth and yield of green bean plants using plant resistance inducers and biological seed treatments. J. Agric. Tech. 11: $1219-1234$.

El-Mougy NS, Nadia G and Abdel-Kader M (2007). Control of wilt and root rot incidence in Phaseolus vulgaris $L$. by some plant volatile compounds. J. Plant Prot. Res. 47:255-265.

Gomez KA and Gomez AA (1984). Statistical Procedures for Agricultural Research. Singapore, John Wiley \& Sons, 39$153 \mathrm{pp}$.

Hamid A, Bhat NA, Sofi TA, Bhat KA and Asif M (2012). Management of root rot of pea (Pisum sativum L.) through bioagents. Afr. J. Microbiol. Res. 6: 7156-7161.

Hoyos-Carvajal L, Orduz S and Bissett J (2009). Growth stimulation in bean (Phaseolus vulgaris $L$.) by Trichoderma. Biol. Control 51: 409-416.

Nashwa MA, Sallam KAM, Abo-Elyousr and Hassan MAE (2008). Evaluation of Trichoderma species as biocontrol agents for damping-off and wilt diseases of Phaseolus vulgaris L. and efficacy of suggested formula. Egypt. J. Phytopathol. 36: 81-93.

Negi DS, Sharma PK and Gupta RK (2014). Management of root-rot complex disease and assessment of plant growth promoting characters in vegetable pea with native and commercial antagonistics through seed biopriming. Int. J. Recent Sci. Res. 5: 1416-1421.

Pan S and Das A (2011). Control of cowpea (Vigna sinensis) root and collar rot (Rhizoctonia solani) with some organic formulations of Trichoderma harzianum under field condition. The J. Plant Prot. Sci. 3: 20-25.

Prajapati BK and Patil RK (2017). Bio-efficacy of Trichoderma spp. and its liquid culture filtrate on mycelial growth and management of onion black mould rot (Aspergillus niger) in vitro and in vivo. Indian Phytopath. 70: 58-62. 